\title{
FRAUD OR MALICE AS A BASIS FOR CIVIL IMPRISONMENT
}

Imprisonment of a judgment debtor on civil process has been retained in many American jurisdictions as a sanction against the commission of two types of torts, those involving some element of "malicious" conduct, and those resulting from some fraudulent action by the debtor in the evasion of a judgment against him.

"Malice," in the sense in which the courts of Illinoiss and Vermont ${ }^{2}$ use it as a basis for civil imprisonment, does not mean spite or ill will, the common definition, ${ }^{3}$ but merely conscious wrongdoing. Thus, torts such as trespass, conversion, fraud and deceit, malicious prosecution, slander, wilful and wanton negligence, and criminal conversation have all been held to be malicious when the courts have found them to have been done in utter disregard of the rights of others. ${ }^{4}$ In the words of the Illinois Supreme Court, 5 after it had reviewed and approved the earlier cases, the term, "malice,"

.... applies to that class of wrongs which are inflicted with an evil intent, design, or purpose; implies that the guilty party was actuated by improper or dishonest motives; and requires intentional perpetration of an injury or wrong on another. However, the term does not necessarily mean that the person committing the injury bears any spite, grudge, or ill will towards the person against whom the wrong is inflicted. ${ }^{6}$

The conception of "malice" is analogous to that found in Section r7a(2) of the Federal Bankruptcy Act,7 which provides that no debts "for wilful and malicious injuries to the person and property of another" shall be dischargeable

I See In re Blacklidge, 359 Ill. 482 , I95 N.E. 3 (I935) (the earlier decisions are here reviewed and approved); In re Teiszerski, 272 IIl. App. 305 (r933).

a Fisher v. Com'rs, 3 Vt. 328 ( 1830 ); Whiting v. Dow, 42 Vt. 262 (I869); North Adams Co. v. Cantor, $\mathrm{IO}_{3} \mathrm{Vt}$. 514, I56 Atl. 879 (I93I). For the relation of the imprisonment cases to the bankruptcy problem see In re Cote, 93 Vt. Io, 106 Atl. 5 I9 (Igr8).

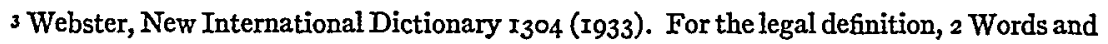
Phrases 622 (4th ser. 1933).

4 Mullin v. Spangenberg, II8 Ill. 55I, 9 N.E. 208 (I886) (trespass); In re Todd, 246 Ill. App. 587 (I926) (trespass was not malicious); Nat'l Bank v. Burkett, Ior Ill. $39 \mathrm{I}$ (I882) (fraud and deceit); Greener v. Brown, 323 Ill. 22x, I53 N.E. 825 (rg26) (trover); Kellar v. Norton, 228 Ill. 356, 8I N.E. ro37 (1907) (trover-not malicious); Beckman v. Menge, 82 IIl. App. 228 (I899) (malicious prosecution); In re Warnke, 207 Ill. App. 459 (IgI7) (slander); Chalukinis v. Jozwiak, 287 IIl. App. I7o, 4 N.E. (2d) 782 (I936) (wilful and wanton negligence); Buck v. Alex, 350 III. I67, I82 N.E. 794 (r932) (mere negligence-not malicious); In re Blacklidge, 359 Ill. 482, I95 N.E. 3 (1935) (criminal conversation).

5 Lipman v. Goebel, 357 Ill. 315, I92 N.E. 203 (1934).

"Malice" in the legal sense includes all those acts which would be considered malicious by the layman, but it also includes a class of acts which were merely done intentionally without consideration of duties owed to others. See Holmes, Privilege, Malice, and Intent, 8 Harv. L. Rev, $x$ (1894).

${ }^{7} 42$ Stat. 354 (I922), II U.S.C.A. $\$ 35$ (2) (I927). 
under the provisions of the act. "The malice here intended is nothing more than that disregard of duty which is found in the intentional doing of a wilful act to the injury of another." The provisions of this act cover all cases in which the facts of intent and malice have been judicially ascertained; 9 and it is not surprising that a debt arising out of an Illinois adjudication that the debtor committed a malicious act, will not be dischargeable in a subsequent bankruptcy proceeding in the federal court..0 Although the state court's finding is not res judicata, the same test of malice will be applied in both courts. ${ }^{\text {Ix }}$

Civil imprisonment, as it exists today in Illinois, ${ }^{{ }^{2}}$ is based on two statutesChapter 77 on Judgment, Decrees, and Executions and Chapter 72 on Insolvent Debtors. ${ }^{x 3}$ The former provides for an execution against the body of the defendant "when the judgment shall have been obtained for a tort committed by such defendant, and it shall appear from a special finding of the jury .... that malice is the gist of the action and.... when the defendant shall refuse to deliver up his estate for the benefit of creditors." ${ }^{\prime 2}$ Another section of the statute explains this latter clause by telling when and how the execution may issue if the creditor "verily believes" that the judgment debtor is concealing assets not exempt from execution, and an execution against his property has been returned unsatisfied. The creditor must make affidavit to the court stating that "such debtor has estate, goods, chattels, lands and tenements not exempt from execution, which he refuses to surrender, or that since the debt was contracted or the cause of action accrued, the creditor has conveyed, concealed, or otherwise disposed of some part of his estate, with design to secure same to his own use, or defraud his creditors. ...." Is If the court approves the affidavit, the body execution will issue. The execution may be had as of right when there has been a finding of "malice" in a tort action, but the affidavit is necessary whenever the debtor's fraudulent action prevents the creditor from levying against non-exempted property. ${ }^{16}$

${ }^{8}$ Collier, Law and Principles of Bankruptcy $\$ 554$ (Gilbert's ed. 1937); Tinker v. Colwell, I93 U.S. 473 (I904); 15 Minn. L. Rev. 700 (I93I).

${ }^{9}$ Collier, op. cit. supra note 8 , at $\$ 554$.

ro United States ex rel. Weber v. Meyering, 66 F. (2d) 347 (C.C.A. 7 th I933).

xI Lipman v. Goebel, 78 F. (2d) 872 (C.C.A. 7 th $x 935$ ), cert. den. 294 U.S. $7 \times 2$ (r935). See note 5 supra.

${ }^{12}$ The subject has been discussed more fully with respect to Illinois by Parnass, Imprisonment for Civil Obligations in Tllinois, $x_{5}$ Ill. L. Rev, 559 (I92x). In 1935 an amendment, Ill. L. $1935, \S \mathrm{I}, \mathrm{p} .937$, to $\S 5$ of the Judgments statute introduced the requirement of a special finding of malice by the jury as the basis for the issuance of a body execution. Prior to this change many cases dealt with the determination of "malice," Jernberg v. Mix, I92 Ill. 254, 65 N.E. 242 (IgO2); Kitson v. People, I32 Ill. 327, 23 N.E. IO24 (I890).

${ }_{3}$ Ill. Rev. Stat. (I937).

${ }^{4}$ IIl. Rev. Stat. (I937) c. 77, § 2; Ingalls v. Raklios, 2 I N.E. (2d) 856 (Ill. App. I939).

25 Ill. Rev. Stat. (I937) c. 77, $\$ 65$.

${ }^{16}$ In re Fetz, 239 III. App. 250 (I926). 
The insolvent debtor's act ${ }^{77}$ sets up the procedure by which all civil prisoners, other than those incarcerated on "malice counts" may seek release from prison. ${ }^{18}$ The procedure established is similar to that found in federal and state insolvency statutes, ${ }^{19}$ and provides for a petition by the imprisoned debtor, notification of the creditor, a scheduling of assets, an assignment of these assets to a third party for the benefit of all creditors, and subsequent discharge of the debtor from prison, following a hearing in which the creditor may oppose the discharge if he so desires. ${ }^{20}$ Release from imprisonment does not, however, extinguish the judgment debt, although $\$ \mathrm{I} .5^{\circ}$ is credited against the debt for each day the debtor remains in prison..$^{2 x}$ Furthermore, the debtor may never be imprisoned again on the same judgment. ${ }^{22}$ Since a "malice count" prohibits the prisoner from taking advantage of the insolvent debtor's procedure, he must remain in jail for six months, the maximum period provided by the act..3 An offer by the debtor to surrender his property will be to no avail ${ }^{24}$ and it does not seem to make any difference whether he could satisfy the judgment or not, once the execution against his person has issued.

Similar procedures for relief from civil imprisonment are found in other states, although only four, ${ }^{25}$ Colorado, Pennsylvania, Rhode Island, and Vermont, contain a provision similar to that of Illinois prohibiting certain classes of tort debtors from taking advantage of the insolvency act until a fixed time has elapsed; the legislatures of Colorado, Pennsylvania and Rhode Island enumerate certain specific torts, while the Vermont statute talks in terms of "wilful and malicious injuries to persons or property." ${ }^{26}$

${ }_{7}$ Ill. Rev. Stat. (1937) c. 72.

${ }^{28}$ Others who may take advantage of this chapter include other tort debtors and debtors in jail for non-payment of miscellaneous civil obligations-fines, court costs or taxes, and judgments in bastardy, wife abandonment, or alimony proceedings. See note $4 \mathrm{r}$ infra.

${ }^{x}$ II U.S.C.A. \$\$ 4I-6I (I927); Pa. Stat. Ann. (Purdon, I930) tit. 39. Many states have omitted general insolvency laws from their revised statutes on the theory that the state statutes have been superseded by the federal bankruptcy act.

${ }^{20}$ IIl. Rev. Stat. (I937) c. $72, \S \S 3,5-7,9,13$. Should the creditor file a traverse of fraud, the debtor must submit to a jury trial, but on conviction he may still take advantage of the provisions of Section 5 of the insolvency act.

2x Ill. Rev. Stat. (1937) c. 72, \$\$ 32-3.

22 Ill. Rev. Stat. (1937) c. 72, $\$ 25$.

${ }_{23}$ Ill. Rev. Stat. (1937) c. 72, 833 . He may remain longer if he refuses to schedule his property at the end of six months.

24 Lipman v. Goebel, 357 IIl. 3I5, I92 N.E. 203 (1934).

${ }_{25} \mathrm{~Pa}$. Stat. Ann. (Purdon, I930) tit. 39, § I00; R.I. Gen. Laws (r923) § 5475; Vt. Pub. Laws (1933) §\& 2192, 2208; Colo. Stat. Ann. (Michie, I935) c. 93, § 72-6.

${ }^{26}$ Maine does not allow release if the action was for a wilful trespass, Me. Rev. Stat. (1930) c. $124, \S 80$. 
Although the release statutes vary little from state to state, ${ }^{27}$ the procedures for imprisonment differ more radically. Besides the group of states with statutes similar to that of Illinois, two other classifications are apparent. ${ }^{28}$ One group of states, including Virginia and Washington, provides that if an execution against the debtor's property is returned unsatisfied the creditor may ask for a hearing at which the debtor must answer interrogatories. If he fails to answer, if he is evasive, or if the court decides that he has property which he refuses to surrender, the debtor may be cited for contempt and imprisoned. ${ }^{29} \mathrm{~A}$ few other states have an identical procedure, in addition to other provisions for civil imprisonment, as a supplemental aid to execution against property..$^{30}$ Finally, the other and larger group, including New York and California, has civil imprisonment only for fraudulent conduct. ${ }^{3 x}$ The statutes vary to some extent between states, ${ }^{32}$ but provide essentially the following procedure: If the debtor might have been arrested for the action as a prelude to the trial, he may be imprisoned after the judgment. The defendant may be arrested on an affidavit containing one or more of the following allegations: (I) he is about to leave the state or about to remove property not exempt from attachment, (2) he has committed an injury to the person or property of the plaintiff, (3) he has

${ }^{27}$ Some states provide for "poor debtor oaths," i.e., the prisoner may be released only if he takes an oath that he possesses no more than a small amount of money, $\$ 20$ to $\$ 50$, not exempt from execution. Vt. Pub. Laws (I933) § 2208; Cal. Code Civ. Proc. (Deering, I937) § I 48 . For other states having assignment procedures similar to Illinois, see Del. Rev. Code (I935) $\S 5$ rog; S.C. Code (r932) $\S 854$. As it is generally conceded that an oath does not have the force it formerly had, the latter procedure is considered better suited to modern conditions, Ginsburg, The Poor Debtor Law, 8 Boston U. L. Rev. 23 (I928).

${ }^{28}$ Alabama, Arizona, Florida, Georgia, Louisiana (except for public officers), Minnesota, Mississippi, Montana, Tennessee, Texas, and the District of Columbia have no provisions for civil imprisonment. It is noteworthy that many of the states having no laws are southern or western states, where the debtor class wielded political power at the time (during the nineteenth century) when statutes of this character were passed, while eastern states, where the financial interests of the country are centered, have the strictest laws.

${ }^{29}$ Va. Code Ann. (Michie \& Sublett, $x 936$ ) $\$ \S 6421,6506$; Washington Rev. Stat. Ann. (Remington, I932) $\$ 6 \mathrm{I}_{3}$. Oklahoma and New Mexico are other states. "Contempt," in the sense that it is used in these statutes, is the same as civil contempt which is found in every state as punishment for defiance of decrees of the courts.

${ }^{30}$ Oregon, Rhode Island, New York, and Colorado.

${ }^{3 x}$ Cal. Code Civ. Proc. (Deering, I937) $\$ \$ 478-504$, Ir43-54; Idaho Code Ann. (r932) \$ 6-ror-6-127; Kan. Gen. Stat. Ann. (Corrick, r935) \$\$60-3470-60-3479; Nev. Comp. Laws (Hillyer, x929) $\S \S 8643-79 ;$ N.Y. Civ. Prac. Ann. (Gilbert-Bliss, Supp. 1939) $\$ \S 764$, 826 ; N.C. Code Ann. (Michie, I935) $\$ \$ 674,767$, I63x; N.D. Comp. I. Ann. (rgr 3 ) $\$ \$ 7489$, 77I7, 8483-95; Ohio Code (Throckmorton, 1936) $\$ \$$ II744-53; S.C. Code (r932) $\$ \S 2384$, 2636, 3030; Wis. Stat. (r937) $\$ \S 272.10,264.01$, c. 336; Wyo. Rev. Stat. Ann. (Courtright, I93 г) $\$ \$ 89-2902,89-3201-89-3230$.

${ }^{32}$ The statutes of some states exempt women from body execution if they have not been arrested before trial, N.Y. Civ. Prac. (Gilbert-Bliss, Supp. I939) $\$ 765$. Cf. Cal. Code Civ. Proc. (Deering, $x_{937)} \S 478-504$, in which there is no such provision. 
fraudulently concealed, conveyed, converted, or otherwise disposed of some of his assets in fraud of creditors, (4) he is accused of the breach of a promise to marry, (5) he, an attorney, public officer, or factor, has misapplied or appropriated to his own use funds entrusted to his possession, (6) he has gambled an amount in excess of $\$ 200$, or $(7)$ he contracted the debt without intending to pay it. ${ }^{33}$ Limitations on the imprisoned debtor's right to take advantage of the insolvency procedure are negligible as almost all the states in the New York group provide that the debtor may petition for release within ten to thirty days after incarceration. ${ }^{34}$

With the exception of New Jersey, where seducers are imprisoned for three years without being allowed to follow the statutory insolvency procedure ${ }^{35}$ only the states that retain the "malice count" have retained the old practice of civil imprisonment in a vigorous form. In the other states, the prisoner "takes the key to his cell with him," and may seek his own release through payment of the debt or a petition of insolvency.

The procedures for imprisonment under civil process have been held not to infringe the state constitutional limitations and prohibitions against imprisonment for debt. ${ }^{36}$ Thirty-nine state constitutions contain these limitations, although expressing them in various forms. ${ }^{37}$ Someprohibit imprisonment for debt; others limit it to cases in which "there is a high presumption of fraud." ${ }^{8}$ In the nine states ${ }^{39}$ which have no constitutional limitations, the statutory provisions differ little from those found in other states. Most courts have interpreted the prohibition against imprisonment for debt to apply to contract but not to tort judgments. $4^{\circ}$ Even the courts of the states prohibiting imprisonment on both

33 Not all of the seven categories are to be found in all the states of this group. The Oregon legislature has provided a similar procedure for the arrest of the defendant, but does not make any regulation for the execution against the body after judgment, Ore. Code Ann. (1930) \& 4IOI.

34 However, Michigan is unique in that it provides different times when the imprisoned debtor may petition for release, depending on the size of the judgment against him, Mich. Comp. Laws (1929) \& 15366 .

3s N.J. Rev. Stat. (I937) tit. 2, c. $35, \S 27$.

${ }^{36}$ In re Blacklidge, 359 Ill. 482 , r95 N.E. 3 (I935); Ex parte Hollman, 79 S.C. 9, 60 S.E. I9 (I908); Thuringer v. Bonner, 74 Colo. 539, 222 Pac. III8 (I924); Bray v. State, I40 Ala. 72,37 So. 250 (I903).

37 See Index Digest of State Constitutions 759 (N.Y. St. Const. Conv. Com'n, I9r5).

$3^{8}$ Illinois Const. art. $2, \S$ I2.

39 Connecticut, Delaware, Louisiana, Maine, Massachusetts, New Hampshire, New York, Virginia, and West Virginia.

$4^{\circ}$ People v. Cotton, I4 Ill. 4I4 (1853); Buck v. Alex, 350 IIl. 167, I82 N.E. 794 (1932). For a more complete analysis see footnotes to Modern Survival of Imprisonment for Debt, 37 Yale L.J. 509, 5 I2 (x928). See also 4r Harv. L. Rev. 786 (r928). These two notes analyze in a more complete manner the constitutional remnants of imprisonment for debt. Cf. Bronson v. Syverson, 88 Wash. 264, I53 Pac. I039 (Igr5) (a tort judgement is a "debt"). 
contract and tort judgments have held that the phrase does not apply to the non-payment of fines, penalties, taxes, or court costs-debts owed to the state..$^{4 x}$ Imprisonment for contempt of a court order to pay over a specific fund is not "imprisonment for debt" within the meaning of the constitutional provisions, ${ }^{42}$ although confinement for contempt of an order to pay a sum of money, e.g., an order following a decree of specific performance against the purchaser under a land contract, is not permitted.43

The so-called "malice count" in Illinois and the extended period in which a defendant must remain in jail for non-payment of judgments for certain specified torts in a few other states provides a quasi-criminal procedure as the result of a civil action. Montana has recognized the criminal nature of these proceedings by making conveyances in fraud of creditors a misdemeanor. ${ }^{44}$ Imprisonment for any type of offense is frequently justified by stating that it is punishment for some unlawiul act or omission. Perhaps a better reason is that it serves as a deterrent and acts as a stimulus to proper behavior in order to protect an important public interest. 45 In fact, the principal advantage of civil imprisonment, as of other civil punishment such as punitive damages, ${ }^{46}$ is that it tends to deter oppressive conduct, such as slanders, assaults, and minor cruelties, which are theoretically criminally punishable, but which in actual practice frequently are ignored by prosecutors perhaps occupied with more serious crimes. ${ }^{47}$ Because of this criminal nature, it would be natural to expect

${ }_{42}$ Kennedy v. People, I22 Mll. 649, r3 N.E. 2r 3 (r887) (fine, court costs); Ruggles v. State, I20 Md. 553, 87 Atl. ro80 (rgr3) (fine for not securing a license); Leonard v. Bolton, I 53 Mass. 428 ( 1890 ) (penalty assessed following a bastardy action); Chicago v. Morell, 247 IIl. 383,93 N.E. 295 (rgro) (wheel-tax); In re Diehl, 8 Cal. App. 5I, 96 Pac. 98 (Igo8) (license tax); Ex parte Robertson, 39 Tex. Crim. 628, II S.W. 669 (I889) (court costs).

It is suggested that the imprisonment in these cases is justified not on the basis that it is for debt but for neglect or refusal to perform a moral or legal duty, the performance of which is within the ability of the debtor, 3 Freeman, Executions 2395 (3d ed. xgog). This reasoning might also explain the instances in which imprisonment follows a fraudulent evasion of the execution against the property of the debtor.

${ }_{42}^{2}$ Tegtmeyer v. Tegtmeyer, 292 Tll. App. 434, xx N.E. (2d) 657 (r937) (failure to pay over a trust fund).

${ }^{43}$ People ex rel. Sarlay v. Pope, 230 App. Div. 649, 246 N.Y. Supp. 414 (I930).

44 Mont. Rev. Codes Ann. (Anderson \& McFarland, I935) § II435.

${ }_{45}^{45}$ Sutherland, Criminology c. Io (I924). $\quad{ }^{46} \mathrm{McC}$ Cormick, Damages c. Io (I93 I).

${ }^{47}$ Although the argument has never been presented to the Illinois court, it is suggested that imprisonment on a "malice count" in a civil suit following acquittal in a criminal trial for the same offense is a violation of the double jeopardy clauses of the United States and Mllinois state constitutions. One Illinois case, White v. Youngblood, 367 Ill. 632, 12 N.E. (2d) 650 (I937), did actually result in the defendant's being imprisoned on a "malice count" after being acquitted of a criminal charge for the same offense. This second proceeding seems to approach very near the point of placing the defendant twice in jeopardy for the same offense. The real obstacle in invoking this doctrine is in establishing the criminal nature of the "malice count" proceeding. That it is criminal is arguable on the basis of the imprisonment which results. The only justification for imprisonment according to modern sociologists, is punishment for the 
that the guaranties which have been developed in favor of the accused person on trial for a crime ${ }^{48}$ would be preserved, especially in view of the general feeling that the taking-away of a person's freedom is an extremely severe punishment. Nevertheless, the usual guaranties in a criminal trial do not exist in behalf of a person defending against a claim of tort with a "malice count," although as a result of non-payment of a judgment against the defendant he can be imprisoned. ${ }^{49}$

The provisions of the insolvent debtors act, prohibiting debtors in jail on "malice counts" from taking advantage of its provisions, have been tested under the due process and equal protection clauses of the Fourteenth Amendment. In one case a judgment had been entered against the defendant for breaking into the plaintiff's office and converting certain valuable papers; he was imprisoned for non-payment and sought release by surrendering his assets. The county court refused his petition, stating that "malice was the gist of the action," and denied him release through the statutory insolvency procedure. The defendant contended, on appeal, that the insolvent debtor's act arbitrarily discriminated against him since it excluded "malicious" tort debtors from the benefits of the statute, but the court held that the act treated all persons in the same position in like manner, and was, therefore, constitutional. The result of the case was that the defendant remained in jail for the maximum statutory period in spite of his willingness to surrender what property he had..$^{\circ}$

Civil imprisonment serves two purposes: to induce payment of a certain type of judgment, which the legislature believed should be satisfied promptly, under the threat of imprisonment, and to give the judgment creditor a legal means of satisfying a desire for revenge against his debtor. That the former result is important in a credit economy no one will doubt, but the latter must be condemned as a vestige of the ancient philosophy that allowed one to seek vengeance upon a fellow man who had wronged him. ${ }^{5 x}$

violation of an important public interest. Thus, it would seem that civil imprisonment, if it can only be justified on the criminal law theory of punishment, is really penal in nature. And the Supreme Court of the United States took exactly this view in Von Hoffman v. Quincy, 4 Wall. (U.S.) 535 (1867), where Mr. Justice Swayne stated: "The right to imprison for debt is not part of the contract. It is regarded as penal rather than remedial. The states may abolish it whenever they think proper."

${ }^{48}$ See U.S. Const. am. 5,6 ; III. Const. art. 2, $\$ \$ 8$-ro. Further, note that most courts hold that a person accused of a crime be presumed innocent until proved guilty beyond a reasonable doubt, that he never can be convicted by default, and that the state may not appeal an acquittal.

49 The procedure on charge of fraud in non-payment of an execution against property will be civil, Morse v. O'Hara, 247 Mass. 183 , I42 N.E. 40 (I924). See Parnass, op. cit. supra note 12.

50 Lipman v. Goebel, 357 Ill. 315, r92 N.E. 203 (1934).

5x For the general history of imprisonment for debt, see Ford, Imprisonment for Debt, 25 Mich. L. Rev. 24 (1926). 